\title{
Review of Carbon Reduction Theory and Calculation Methods of Carbon Emissions in China 's Iron and Steel Industry
}

\author{
Si-yu Liu ${ }^{a 1}$,Jian-xun Fu ${ }^{\text {b1,* }}$,Juan Cheng ${ }^{c 1}$, Hong-qiang Liu ${ }^{\mathrm{d} 1}$ and Huai-bin Han ${ }^{\mathrm{e} 2}$ \\ ${ }^{1}$ State Key Laboratory of Advanced Special Steel; Shanghai Key Laboratory of Advanced \\ Ferrometallurgy; School of Materials Science and Engineering, Shanghai University, \\ Shanghai,China,200072 \\ ${ }^{2}$ Henan Jiyuan Iron and Steel Group Co., Ltd, Henan Jiyuan, China, 459000 \\ bfujianxun@shu.edu.cn \\ ${ }^{*}$ Corresponding author
}

\begin{abstract}
Key words: Steel Industry, Greenhouse Gas, $\mathrm{CO}_{2}$ Emissions, Calculation Method
Abstract: The paper reviews on the carbon reduction theory in Chinese steel industry and introduces three calculation methods of carbon footprint. Provincial Guidelines for Greenhouse Gas Inventories and Accounting Methods and Reporting Guidelines for Greenhouse Gas Emissions in Chinese Steel Producers are calculation methods of greenhouse gas emissions on the enterprise level, established by Chinese government. The calculation method of carbon emissions proposed by Professor Fu Jian-xun, Shanghai University, based on ISO standard, is consistent with that in foreign steel producers. He provided the thought of life cycle analysis and accurately calculated the $\mathrm{CO}_{2}$ emissions top-down and step by step.
\end{abstract}

\section{Introduction}

As we all know, there has been an improving concern about the environmental pollution and energy consumption. In China, iron and steel industry is often associated with high pollution, high energy consumption and high emissions. In the year of 2015, the whole crude steel production was 1.1235 billion tons, which meant nearly 2.5 billion tons of carbon emissions[1].

In 2014, China and America both issued a joint statement to deal with climate change in Beijing[2].The carbon emissions were expected to reach the peak and non-fossil energy raised to $20 \%$ in the proportion of primary energy in 2030. It means that China should speed up economic restructuring, and change the structure of energy consumption. Because of the common problems as not balanced, much backward production capacity, low energy efficiency, high pollution, high emissions and others, steel industry in our country has been always facing with large international environmental pressure. The steel industry in China has been emphasis on carbon emissions and the focus is to reduce it in steel production process. This paper reviews on the carbon reduction theory and calculation methods of carbon emission in China 's steel industry.

\section{Carbon Reduction Theory in Chinese Steel Industry}

Carbon reduction work has been carried out in steel industry for a long time. Sheng Gang[3]and $\mathrm{Wu}$ Yan-guangcontructed of the carbon flow model of coking, sintering, iron making, steel making, rolling and other major processes in steel production process. They established the relationship between carbon sources and carbon-containing products in aspect of matter and energy conservation in production process to provide a theoretical basis for calculating the carbon footprint. Li Ling[4],based on the research status of energy conservation and emission reduction in steel industry, using system dynamics, established the steel demand, energy consumption and CO2 emissions model in steel industry in China. Based on the source analysis of carbon emission in Chinese steel industry, Zhang Chun-xia[5] et al analyzed the current situation and characteristics of greenhouse gas emissions in domestic and international steel industry, noting that greenhouse gas emissions from the iron and steel industry was mainly $\mathrm{CO} 2$ and was mainly caused by energy consumption. YinRui-yu[6]regarded the steel-making process as the driving-interaction network, which interactively formed by the material flow (mainly ferrite flow) and the energy flow (mainly carbon flow).With optimizing the steel-making process based on the material flow and energy flow 
analysis, he established low-carbon green manufacturing and ecological development model for steel industry.

\section{Calculation Methods of CO2 Emissions in domestic Steel Industry}

Provincial Greenhouse Gas Directory[7]. Provincial Guidelines for Greenhouse Gas Inventories is divided into fossil fuel combustion, indirect emissions from the net consumption of fossil fuel combustion and indirect emissions from electricity to be calculated.

Total corporate $\mathrm{CO} 2$ emissions:

$$
\mathrm{E}_{\mathrm{CO}_{2}}=\mathrm{E}_{\mathrm{ffc}}+\mathrm{E}_{\mathrm{ipc}}+\mathrm{E}_{\mathrm{ec}}
$$

Where $\mathrm{E}_{\mathrm{CO}_{2}}-\mathrm{CO} 2$ emissions for one unit of corporateproducts, $\mathrm{kgCO} 2$

$\mathrm{E}_{\mathrm{ffc}}-\mathrm{CO} 2$ emissions from fossil fuel combustion, $\mathrm{kgCO} 2$

$\mathrm{E}_{\mathrm{ipc}}-\mathrm{CO} 2$ emissions from industrial processes, $\mathrm{kgCO} 2$

$\mathrm{E}_{\mathrm{ec}}-\mathrm{CO} 2$ emissions from electricity, $\mathrm{kgCO} 2$

$$
\mathrm{E}_{\mathrm{ffc}}=\sum_{\mathrm{i}=1} \mathrm{AD}_{\mathrm{i}} \mathrm{XEF}_{\mathrm{i}}
$$

Where $\mathrm{E}_{\mathrm{ffc}}-\mathrm{CO} 2$ emissions from the net consumption of fossil fuel combustion , $\mathrm{kgCO} 2$

$\mathrm{AD}_{\mathrm{i}}$ - - Apparent consumption of $\mathrm{i}$ fossil fuel,TJ

$\mathrm{EF}_{\mathrm{i}}$ - The i fuel emission factor, $\mathrm{kg} / \mathrm{TJ}$

$$
\mathrm{E}_{\mathrm{ffc}}=\sum_{\mathrm{i}=1}\left[\left(\mathrm{AD}_{\mathrm{i}} \mathrm{X} \eta_{\mathrm{ic}}-\mathrm{D}_{\mathrm{ic}}\right) \mathrm{X} \phi_{\mathrm{io}}\right]
$$

Where $\mathrm{E}_{\mathrm{ffc}}-\mathrm{CO} 2$ emissions from the net consumption of fossil fuel combustion, $\mathrm{kgCO} 2$

$\mathrm{AD}_{\mathrm{i}}$ - - Apparent consumption of $\mathrm{i}$ fossil fuel,TJ

$\eta_{\text {ic }}$ - Carbon content for per unit calorific value, $\mathrm{kgCO} 2 / \mathrm{TJ}$

$\mathrm{D}_{\mathrm{ic}}$ - Carbon sequestration amount of fuel used for non-energy purposes

$\phi_{\text {io }}$ - Average oxidation rate for burning of $i$ fossil fuel

Carbon sequestration rate refers to a fixed carbon rate when a variety of fossil fuel is used as non-energy material. Since the part of the carbon is not released, it is necessary to be deducted in the calculation of emissions. Carbon oxidation rate refers to the carbon ratio oxidized by a variety of fossil fuel during combustion, characterizing the combustion of fuel. Large amounts of electricity required in steel production process cause indirect greenhouse gas emissions, and this part of emissions is calculated as the following formula:

$$
\mathrm{E}_{\mathrm{ec}}=\mathrm{AD}_{\mathrm{e}} \times \mathrm{EF}_{\mathrm{e}}
$$

Where $\mathrm{E}_{\mathrm{ec}}-\mathrm{CO} 2$ emissions from electricity, $\mathrm{kgCO} 2$

$\mathrm{AD}_{\mathrm{e}}$ - Electricity consumption in steel production process, $\mathrm{kWh}$

$\mathrm{EF}_{\mathrm{e}}-$ - Greenhouse gas emission factor from electricity, $\mathrm{kgCO} 2 / \mathrm{kWh}$

Accounting Methods and Reporting Guidelines for Greenhouse Gas Emissions in Chinese Steel Producers. Accounting Methods and Reporting Guidelines for Greenhouse Gas Emissions in Chinese Steel Producers is more specific than the Provincial Guidelines for Greenhouse Gas Inventories. Input-Output thought[8] is used on the overall level of steel-making to statistic the greenhouse gas emissions in steel production process.

Facilities and services include direct production system, auxiliary production system and ancillary system to service the production. Auxiliary production systems includes power, supplying electricity and water, chemical testing and machine maintenance, warehouse and transportation. Affiliated production system includes command system (factory) and the region to service the 
production such as cafeteria, shop bathroom, health stations, etc. The total of $\mathrm{CO} 2$ emissions in steel production producter is calculated as following:

$$
\mathrm{E}_{\mathrm{CO}_{2}}=\mathrm{E}_{1}+\mathrm{E}_{2}+\mathrm{E}_{3}-\mathrm{R}_{\mathrm{C}}
$$

Where $\mathrm{C}_{\mathrm{CO}_{2}}$ - Total $\mathrm{CO} 2$ emissions in enterprise, $\mathrm{kgCO} 2$

$\mathrm{E}_{1}-\mathrm{CO} 2$ emissions from whole net consumption of fossil fuel combustion, $\mathrm{kgCO} 2$

$\mathrm{E}_{2}-\mathrm{CO} 2$ emissions from the industrial processes in enterprise, $\mathrm{kgCO} 2$

$\mathrm{E}_{3}-\mathrm{CO} 2$ emissions from the electricity and heat in enterprise, $\mathrm{kgCO} 2$

$\mathrm{R}_{\mathrm{C}}-\mathrm{CO} 2$ emissions from the carbon sequestration products

Emissions from the combustion of fuel arecalclulated the same as the Provincial Greenhouse Gas Directory and $\mathrm{CO} 2$ emissions from the industrial processes and carbon sequestration products are calculated as follows:

$$
\mathrm{E}_{2}=\mathrm{P}_{\mathrm{e}} \times \mathrm{EF}_{\mathrm{e}}+\sum_{\mathrm{i}=1}^{\mathrm{n}} \mathrm{P}_{\mathrm{i}} \times \mathrm{EF}_{\mathrm{i}}+\sum_{\mathrm{i}=1}^{\mathrm{n}} \mathrm{M}_{\mathrm{i}} \times \mathrm{EF}_{\mathrm{i}}
$$

Where $\mathrm{E}_{2}-\mathrm{CO} 2$ emissions from the industrial processes in enterprise, $\mathrm{kgCO} 2$

$\mathrm{P}_{\mathrm{e}}, \mathrm{P}_{\mathrm{i}}$ and $\mathrm{M}_{\mathrm{i}}$ - Amount of the electrodes, limestone and dolomite, without sourcing iron and ferroalloy, $\mathrm{kg}$

$\mathrm{EF}_{\mathrm{e}}$ and $\mathrm{EF}_{\mathrm{i}}-$ Carbon emission factors, $\mathrm{kgCO} 2 / \mathrm{kg}$

$$
\mathrm{R}_{\mathrm{c}}=\sum_{\mathrm{i}=1} \mathrm{AD}_{\mathrm{C}} \times \mathrm{EF}_{\mathrm{C}}
$$

Where $\mathrm{R}_{\mathrm{C}}-\mathrm{CO} 2$ emissions from the carbon sequestration product

$\mathrm{AD}_{\mathrm{C}}-$ Output of the i carbon sequestration product

$\mathrm{EF}_{\mathrm{C}}$ - Carbon emission factor of the i carbon sequestration product

However, for the calculation of greenhouse gas emissions in various departments and processes within the steel industry, the two calculation methods can not get a more detailed report. More importantly, they can't research on changes of carbon footprint caused by the changes of material flow and energy in production process.

Calculation Method of Carbon Emission based on ISO Standards. Professor Fu Jian-xun developed a carbon footprint calculation model based on ISO standard in steel production process and proposed a carbon footprint calculation method with the characteristics of Chinese steel industry and developed proprietary software to calculate the carbon footprint. The calculation process is as follows.

(1) Make the steel production processes and system boundaries (fences), based on the production process in each enterprise.(2) Access the method of segment statistics for technologies and the way from top to bottom in the process section to determine the inventory priorities.(3) Count all of the raw materials and energy consumption items involved in the steel production process in order.(4) Summarize the carbon equivalent of aspects of the main process and auxiliary,based on the carbon equivalent coefficient of each material item and energy item.(5) Consider interface coefficient due to the losses between each receiving process and determine the total output according to the system boundary to convert into $\mathrm{CO}_{2}$ emissions for per tonne of steel or the total $\mathrm{CO}_{2}$ emission in steel enterprise.(6) Analysis and evaluate the inventory results and rise up optimization recommendations after the inventory process.

\section{Conclusions}

Provincial Guidelines for Greenhouse Gas Inventories and Accounting Methods and Reporting Guidelines for Greenhouse Gas Emissions in Chinese Steel Producers are emission calculation methods of greenhouse gas on the enterprise level, regard less of concrete processes in steel production. The latter is more specific on system boundary and calculation method. The calculation 
method for carbon emissions proposed by Shanghai University, based on ISO standard, is consistent with that in steel producers abroad. Professor Fu Jian-xun provided a method to accurately calculate the greenhouse gas emissions of each step and established the management approach to calculate data top-down in steel production process.

\section{Acknowledgement}

The authors would like to thank State Natural Science Fund Projects of China(51474142 and 51671124) and China Postdoctoral Science Foundation(2015M580316) for supporting this work.

\section{References}

[1] Informationonhttp:/www.askci.com/news/chanye/2016/02/01/94337tfan.shtml

[2] Informationonhttp://news.xinhuanet.com/2014-11/12/c_1113221744.htm

[3] Sheng Gang,Sun Yan-guang,Xu Hua-yan, et al. Construction of Carbon Flow Model in Joint Steel Venture Process and Research on $\mathrm{CO}_{2}$ Emissions.China Metallurgical, 2011,21(07):1-6.

[4] Li Ling.Research on Carbon Footprint in Chinese Steel Industry based on System Dynamics.Metallurgical Industry Automation, 2011,06:7-10.

[5] Zhang Chun-xia, ShangGuanFang-qin, ZhangShourong, et al. Discussion on GHG emission reduction in the steel industry. Journal of Engineering Studies, 2012,(03):221.

[6] Yin Rui-yu.Manufacturing Power and Times Proposition in Steel Industry.China Metallurgical News, 2013-05-30005.

[7] LIU Hong-qiang, FU Jian-xun, LIU Si-yu. Calculation methods and application of carbon dioxide emission during steel-making process, Iron and Steel, 2016, 51(4): 74-82

[8] Sun Jian Wei, Chen Zhigang, Zhao Rongqin, et al. Research on Carbon Footprint in China based on Input-output Analysis. China Population Resources and Environment, 2010,20 (05):28-34.

[9] Information on http://www.worldsteel.org/ 